\title{
Quando a moda faz a diferença
}

When fashion makes the difference

Resenha de: SILVA, Camila Borges da; MONTELEONE, Joana; DEBOM, Paulo (Orgs.). A história na moda, a moda na história. São Paulo: Alameda, 2019. 


\section{Paulo Knauss ${ }^{1}$}

ORCID: https://orcid.org/0000-0002-5610-0356

Não há dúvida da presença da moda na vida social dos dias de hoje. Não sem razão, a moda tornou-se uma chave de interpretação da sociedade contemporânea e seus dilemas. Nesse sentido, nas últimas décadas, a moda se afirmou como objeto inovador dos estudos acadêmicos a partir de diferentes abordagens disciplinares. Não há dúvida, porém, que o ponto de vista presentista sobre a moda conduziu ao encontro com a pesquisa histórica.

O novo livro $A$ história na moda, a moda na história, organizado por Camila Borges da Silva, Joana Monteleone e Paulo Debom, por meio da reunião de textos de diferentes autores, oferece um panorama da contribuição recente da historiografia sobre a experiência da moda. A coletânea retrata a produção de uma geração de pesquisadores que se debruçou sobre a história da moda e da indumentária apontando caminhos e horizontes para a renovação da historiografia. Tal como o título do livro sugere, a leitura do livro desperta a convicção de que o traje se define como um sujeito que atua e participa da vida em sociedade. Em outras palavras, a ênfase recai no pressuposto de que a ação de se vestir não é inocente, nem neutro, mas se caracteriza como ato social.

Organizado em três partes, o livro é dividido em seis estudos sobre a moda no século XIX e outros cinco sobre a moda em tempos recentes, além de três ensaios de crítica teórica. O último ensaio fecha a coletânea com uma sugestão provocativa de Marco Antônio Vieira que, ao tomar Alexander McQueen e Adriana Varejão como pretexto para a reflexão, defende os hibridismos e as contaminações entre arte, moda e história no sentido de não afirmar verdades absolutas. Assim, no fim do livro, consagra-se o que os outros textos já encaminhavam: a moda é um terreno de pesquisa e interrogação por meio de aproximações disciplinares. Desse ponto de vista, decorre perspectiva uma crítica em relação à historiografia da moda e do vestuário elaborada por Anamelia Fontana Valentim, que defende uma ênfase nas relações entre moda e imagem e promove um diálogo com a história da arte. Camila Borges da Silva, por sua vez, defende uma museologia da indumentária, evitando a clivagem entre moda e costume, considerando que o costume prende-se à tradição e a moda valoriza o novo. Na tensão entre a tradição e o novo, a autora associa as disputas entre lembranças e esquecimentos que são próprios do domínio da memória. Desse modo, destaca-se como a história da moda adentra no terreno da história da memória. Pode-se dizer que a história da moda e das coleções de indumentária depende da construção social do patrimônio cultural.

Na primeira parte da obra, a história da moda e da indumentária no século XIX é relacionada aos sistemas normativos da ordem social e à construção de subjetividades. Esse enfoque desdobra-se em dois ensaios que discutem os sentidos históricos da monarquia no Brasil e na Europa. Enquanto Maria Cristina Volpi aborda a história da criação dos trajes

\footnotetext{
Doutor em História pela Universidade Federal Fluminense. Professor do Departamento de História da Universidade Federal Fluminense. Lattes: http://lattes.cnpq.br/9236533842481264.
} 
majestáticos no Brasil imperial para tratar a ordem simbólica que envolve a monarquia nos trópicos, Paulo Debom discorre sobre como a moda participou de perto da política na França - a partir da análise de imagens do imperador Napoleão III - para caracterizar o Segundo Império como um momento crucial na história das aparências. Outros ensaios exploram a importância da moda na construção de comportamentos sociais no século XIX. Ao identificar as transformações do traje feminino na época do Primeiro Reinado no Brasil, Joana Monteleone caracteriza a participação das mulheres na vida da corte nesse período. Juliana Schmitt, por seu turno, analisa como as formas e os sentidos dos trajes de luto traduziram a complexidade das práticas fúnebres no Brasil oitocentista. As relações entre moda e sentimento são tratadas também no texto de Irina Aragão, que apresenta como a construção da sensibilidade romântica no século XIX expressou-se em uma variação singular de objetos de adorno pessoal que podem ser identificados como joias de afeto e saudade. A relação íntima de compromisso, luto ou memória que a peça suscitava levou à produção de novos formatos e ao uso de diversos materiais, como as inusitadas peças feitas com cabelos humanos, que podiam ser modelados em relevos, laminados ou entrelaçados, por exemplo. Fica evidente que o valor desse tipo de joia sentimental estava menos na sua riqueza material do que na densidade de seu significado.

O último texto da primeira parte do livro, de autoria de Ana Cláudia Suriani da Silva, demonstra como a moda se configurou como uma agência fundamental das transferências culturais entre a Europa e o Brasil. A inspiração decorre da afirmação do escritor oitocentista brasileiro Joaquim Manoel de Macedo, que havia dito que a moda de Paris se entronizou na Rua do Ouvidor, fazendo a cidade do Rio de Janeiro instalar-se nos horizontes do império da moda. Surpreende como, a partir da segunda metade do século XIX no Brasil, a moda ocupou o mundo dos impressos, especialmente as publicações dirigidas ao público feminino, em que a ilustração foi decisiva para configurar o gênero editorial, ainda que o texto predominasse sobre a imagem.

Essa discussão sobre as relações entre moda e o mercado editorial constitui um elo entre os textos da primeira e da segunda parte do livro e, sobretudo, lança uma ponte entre passado e presente. Na segunda parte da obra, os estudos históricos enfatizam outras agências fundamentais de promoção social da moda na história recente, explorando as relações com a sociedade de consumo e a indústria cultural.

Assim, a TV, a partir da criação de figurino, torna-se um universo de interrogação sobre a moda no mundo contemporâneo. No seu estudo, Geanneti Tavares Salomon demonstra como a teledramaturgia elabora os sentidos do traje ao analisar como a prosa realista de Machado de Assis e de seu romance Dom Casmurro foi adaptada e serviu de fonte criativa para a versão simbólica atemporal que é encarnada nos figurinos criados por Beth Filipecki para a minissérie Capitu, que foi ao ar em 2008 sob a direção-geral de Luiz Fernando Carvalho. Se nesse caso a questão artística se coloca, as relações entre criação de figurino e mercado de consumo são exploradas no texto de Maria Claudia Bonadio e Maria Eduarda Araujo Guimarães, que caracterizam como, na década de 1970, as telenovelas brasileiras promoveram a aproximação do traje cênico com o vestuário cotidiano, criando espaço comercial para o merchandising de produtos da moda internacional na dramaturgia de TV.É assim que 
se entende a importância das meias lurex que despontavam na abertura de Dancin' Days, que estreou em 1978, e constituía os laços entre a noite carioca e a cena internacional das discotecas, do mesmo modo que, na novela Roque Santeiro, exibida entre 1985 e 1986, os laçarotes de penteado da viúva Porcina repetiam o figurino de Madonna, a estrela pop que encarna a música globalizada contemporânea. Tal como apontam as autoras, os vínculos entre TV e consumo são tão intensos que no mercado se estabelece a categoria de peça de novela. As conexões do mercado que entrelaçam as indústrias da cultura e da moda são discutidas ainda no texto de Juliana Schmitt e Gabriel Sanchez, no qual discorrem como a cultura pop da década de 1980 expôs o debate sobre a questão de gênero afirmando uma pauta agender que foi apropriada pela indústria da moda recente e que inverte o binarismo estabelecido ao longo da história pelo controle social da roupa.

Como não poderia deixar de ser, a questão da criação de moda de marca autoral é tratada em dois outros textos que exploram o contexto social do Brasil nas décadas de 1960 e 1970, marcado pelo golpe de estado de 1964. No primeiro texto, Maria do Carmo Rainho relembra a história da instalação do ateliê carioca de Jacques Heim, costureiro francês de alta-costura, no fim dos anos de 1950, em parceria com a grande loja de departamento local Mesbla. A repercussão da iniciativa de o costureiro francês se estabelecer no outro lado do Atlântico apontava a disposição em disputar o mercado carioca da alta-costura, dominado localmente pela Casa Canadá que, tradicionalmente, representava diferentes maisons francesas na cidade. A disputa por clientes mobilizou várias personalidades femininas de destaque social. Jacques Heim representava uma novidade que desafiava a tradição da Casa Canadá na cidade e a divisão da clientela assumia contornos sociais alargados. Assim, em certa ocasião, Letícia Lacerda, esposa do governador da Guanabara Carlos Lacerda, foi vista em um desfile, enquanto a primeira-dama Maria Teresa Goulart, esposa do presidente João Goulart, participava do evento da outra casa. As disputas da moda eram transferidas até mesmo para a arena política. No estudo de Janaína de Almeida Teles, acompanhamos ainda a história do projeto comercial de Zuzu Angel, que buscava a internacionalização de uma marca brasileira. Essa trajetória, no entanto, sofreu uma reviravolta por causa dos desafios pessoais enfrentados pela estilista que decorreram do desaparecimento de seu filho pela ação das forças da repressão política em tempos de ditadura. Não há dúvida de que moda é uma questão política, que a história confirma, seja em jogos de mercado ou nas lutas sociais.

Ao fim da leitura dos ensaios históricos reunidos o que se oferece ao leitor é um leque de possibilidades para se pensar os significados da moda ao longo da história. A coletânea de textos afirma a riqueza da pesquisa sobre a história da moda no Brasil, mas, sobretudo, destaca como a história da moda pode ser inovadora ao se valorizar o traje como um sujeito que atua e participa da sociedade, mobilizando pessoas, grupos sociais e instituições. 0 inusitado da história da moda é justamente ultrapassar o senso comum de que tratar de moda é permanecer no terreno do frívolo e diletante. Nesse caso, pode-se dizer que a pesquisa histórica faz a diferença e desloca o pensamento. 